УДК 330

\title{
СТРАХОВОЕ МОШЕННИЧЕСТВО В ЛИЧНОМ СТРАХОВАНИИ, СПОСОБЫ БОРЬБЫ, ИННОВАЦИИ СТРАХОВОГО РЫНКА
}

\author{
Баранников Роман Федорович \\ магистрант
}

Санкт-Петербургский государственный университет

\begin{abstract}
Аннотация: В настоящей статье рассмотрены основные типы мошенничества в личном страховании, уделено внимание современным и практически опробованным способам борьбы с мошенничеством, что ведет к повышению эффективности работы страховых подразделений продаж. Инновации в страховании способствуют появлению высокорентабельных продуктов с низкими рисками мошенничества.
\end{abstract}

Ключевые слова: страховое мошенничество, инновации, оппортунистическое мошенничество, телемедицина, цифровизация, страховой рынок, личное страхование, ДМС, COVID-19.

\section{INSURANCE FRAUD IN PERSONAL INSURANCE, METHODS OF STRUGGLE, INNOVATIONS OF THE INSURANCE MARKET}

\section{Barannikov Roman Fedorovich}

\begin{abstract}
In this article, the main types of fraud in personal insurance are considered, attention is paid to modern and practically tested methods of combating fraud, which leads to an increase in the efficiency of insurance sales units. Innovations in insurance contribute to the emergence of highly profitable products with low fraud risks.
\end{abstract}

Key words: insurance fraud, innovation, opportunistic fraud, telemedicine, digitalization, insurance market, personal insurance, VMI, COVID-19

Страховое мошенничество - умышленное действие, совершенное субъектами договора страхования, третьими лицами против имущественных интересов страховой организации с целью получения материальных выгод, а также действия со стороны страховых организаций, в том числе фиктивных, выраженных в недобросовестных практиках продаж страховых услуг, 
необоснованном отказе или занижении сумм выплаты страхового возмещения. Личное страхование - совокупность видов страхования (отрасль страхования), где в качестве объекта страхования выступает имущественный интерес страхователя, связанный с жизнью, здоровьем, событиями в жизни отдельного человека. Под личным страхованием на рынке РФ подразумевается страхование от несчастного случая, страхование жизни, страхование выезжающих за рубеж, добровольное медицинское страхование. Исторически мошенничество началось именно в личном страховании ввиду популярности и значимости данного вида, а также возможности осуществить какие-либо незаконные действия, не имея имущественного капитала или объекта собственности, ведь жизнь и здоровье имеют все граждане, соответственно и осуществить мошенническое действие способен любой дееспособный гражданин. Существует спонтанное страховое мошенничество (в зарубежной практике - мягкое мошенничество (soft fraud) [1, c. 108], иногда также называют оппортунистическим мошенничеством. Этот вид мошенничества характерен даже для добросовестных страхователей, преувеличивающих свои законные требования. Спонтанное мошенничество может также иметь место, например, когда при получении нового полиса медицинского страхования человек искажает предыдущие или существующие условия, чтобы получить более низкий страховой тариф по полису страхования [2, с. 151]. В России данные ситуации часто возникают, например при ипотечном страховании как со стороны страхователя (неверные сведения о состоянии здоровья заемщика), так и со стороны представителя страховщика (менеджер по ипотечному страхованию формально относится к заполнению анкеты состояния здоровья заемщика).

Возможность влияния клиентов на свою заболеваемость и смертность означает для страховой компании появление дополнительного риска при проведении личного страхования. При этом речь идет не столько о целенаправленных поступках, сколько о косвенном воздействии поведения страхователя. Могут иметь место такие факторы, как опасные для здоровья условия работы либо хронические заболевания, которые не были учтены при оформлении страхового договора. Потери страховой компании от подобных случаев могут быть довольно весомыми, поэтому с целью снижения данного риска страховщик может: уделять особое внимание использованию в договоре о страховании таких формулировок, которые бы могли спровоцировать увеличение убыточности; анализировать эффективность различных каналов продаж, результатов деятельности отдельных агентов и брокеров а также 
сотрудников и менеджеров по страхованию; проводить дополнительный андеррайтинг, включая получение дополнительной информации о конкретном риске; регулировать убытки с большим профессионализмом; проводить текущий актуарный анализ прошлых и действующих договоров страхования. Необходимо более тщательное регулирование и на законодательном уровне, в настоящий момент времени предоставление неполной или некорректной информации не всегда является аргументом в пользу отказа от страховой выплаты, судебная система РФ настроена более лояльна по отношению к страхователям чем к страховщикам, при этом нарушения самих страховщиков при заключении договоров страхования (на момент оформления) также подробно не анализируются.

И так, рассмотрим на примере разных видов личного страхования возможные пути борьбы со страховым мошенничеством. В рамках сотрудничества по договорам добровольного медицинского страхования, страховые компании могут быть подвержены мошенническим действиям со стороны медицинских учреждений. Чтобы минимизировать потери, страховщикам следует приглашать врача-контролера под видом пациента в медицинские учреждения; вести максимально детальный статистический учет убыточности с видом всех медицинских услуг каждому конкретному страхователю; иметь высококвалифицированный персонал в диспетчерской ДМС страховой компании. При страховании жизни возможны мошеннические действия, связанные с убийствами или с инсценировкой смерти. Необходимо при принятии на страховании учитывать сомнительный крайне высокий интерес заинтересованного лица к данному виду личного страхования (страховой агент как психолог); официальный доход и социальный статус клиента; кредитная история должна проверяться через службу безопасности страховой компании особенно при высоких страховых суммах; страховые суммы должны быть ограничены и соответствовать реальным суммам дохода гражданина; необходима тщательная экспертная проверка документов со стороны страховой компании при наступлении страхового случая; необходима проверка документов страхователя до принятия на страхования. К сожалению, в гонке за страховыми премиями и бонусами страховщики часто игнорируют некоторые аспекты собственной безопасности, что безусловно ведет к росту мошенничества особенно в период кризисных явлений современного мира [3, с. 83]. Если мы говорим про страхование выезжающих за рубеж, то основной объем продаж осуществляется через турфирмы, и здесь важно контролировать деятельность данных посредников. 
Вести строгий учет БСО и контролировать неоплаченные начисления. Работа должна осуществляться под конкретными доступами в электронной системе страховой компании официально разрешенным сотрудникам турфирмы. Весь документооборот должен быть электронный, таким образом появляется возможность восстановить поминутную цепь событий в момент наступления страхового случая. Работа в электронных системах компании позволяет избежать страхования задним числом, подделки страхового договора, некорректных внесений данных страхователя. Важно формировать комплект документов на каждого застрахованного и хранить данную информацию в собственных системах компании, создавая ту или иную историю страхователя.

В целом, если обратиться к иностранному опыту и обобщить методы борьбы [4, с. 383] с мошенничеством я бы выделил несколько основных аспектов: 1) необходимо создать единую базу данных страховщиков по личному страхованию (аналог базы РСA); 2) должна быть создана независимая ассоциация по борьбе с мошенничеством, куда страховщики отчисляют взносы; 3) должен быть создан единый конфиденциальный номер доверия для граждан и страховщиков пострадавших в результате мошенничества; 4) совершенствование законодательной системы.

Инновации страхового рынка напрямую связаны с внешними факторами и имеют процесс ускорения под влиянием COVID-19. В настоящее время при активной цифровизации, при дистанционной деятельности страховщиков и как следствие усилении работы электронного документооборота в момент оформления договоров личного страхования и при получении страховых выплат усложнились и возможные пути мошенничества. Сейчас мы имеем мобильные приложения, все виды личного страхования в нем, а также возможность оплаты полисов через QR-код мгновенно и урегулирование претензий через данное приложение. Мы получаем полисы в электронном виде, нам не нужно тратить время и деньги на доставку. Банки принимают сейчас электронные ипотечные полисы с электронной цифровой подписью (ЭЦП), что безусловно ускоряет внедрение безопасных ипотечных сделок. Происходит активное развитие телемедицинских услуг как в России, так и во всем мире. Как следствие растут продажи полисов телемедицины [5, с. 35], при достаточно низкой убыточности и $0 \%$ мошенничества по данному продукту. Наступает Новая эра на рынке ДМС в виде развития дистанционных услуг. В современном мире все сложнее совершить незаконное действие не оставив «след» в информационных системах. 
Развитие технологий, автоматизация и переход в он-лайн режим способствует более эффективной борьбе с мошенничеством в области личного страхования и других видов страхования.

\section{Список литературы}

1. Viaene, Stijn; Dedene, Guido. Insurance Fraud: Issues and Challenges // The Geneva Papers on Risk and Insurance. - 2005. - Апрель (т. 29, № 2). - С. 316.

2. Шеслер А.В. Проблемы квалификации мошенничества / А. В. Шеслер // Вестн. Владим. юрид. ин-та. - 2013. - № 1(26). - С. 151-154.

3. А.И. Алгазин, А.Б. Жуков. Защита бизнеса от страхового мошенничества. - Москва: «Проспект», 2021. - С. 83-87. (Библиотека страхового детектива).

4. А.И. Алгазин, Н.Ф. Галагуза, В.Д. Ларичев. Страховое мошенничество и методы борьбы с ним. - Москва: «Дело», 2003. - 512 с. (Банковское и финансовое право).

5. Болдырев Б.М. Телемедицина в страховании // Страховое дело. 2017. № 6 (291). C. 35-45. 